\section{Results from Hop Cultivar Trials in Mid-Atlantic United States}

\author{
Laban K. Rutto ${ }^{1}$, Yixiang Xu ${ }^{1}$, Shuxin Ren ${ }^{1}$, Holly Scoggins ${ }^{2}$, \\ and Jeanine Davis ${ }^{3}$
}

ADDITIONAL INDEX WORDs agronomic performance, climatic factors, cone quality, diseases, Humulus lupulus, pests

\begin{abstract}
Summary 'Hop' (Humulus lupulus) cultivar trials were conducted at sites in three Virginia counties (Northampton, Chesterfield, and Madison) in response to demand by the craft beer industry for local ingredients. In 2016, a replicated study involving five cultivars (Cascade, Chinook, Newport, Nugget, and Zeus) was established on an 18-ft-tall trellis system at each site. Weather data influencing infectivity of downy mildew (Pseudoperonospora bumuli) and powdery mildew (Podosphaera macularis), two economically important hop diseases, was collected, and to the extent possible, similar cultural practices were applied at each site. Climatic conditions favorable to $P$. humuli and $P$. macularis were present throughout the experimental period, and $P$. humuli infection was widespread at all sites starting from 2017. Among common pests, Japanese beetle (Popillia japonica) was the only one observed to cause significant damage. Unseasonably high rainfall in 2018 led to crop failure at all but the

Northampton site, and harvesting was done at all sites only in 2017 and 2019. Yields (kilograms per hectare by weight) in 2017 were found to be $\geq 45 \%$ lower than second-year estimates for yards in the north and northwestern United States. Quality attributes ( $\alpha$ and $\beta$ acids; essential oil) for cones harvested from the Chesterfield site were comparable to published ranges for 'Cascade' in 2019, but lower for the other cultivars. More work is needed to identify or develop cultivars better suited to conditions in the southeastern United States. The influence of terroir on quality of commercial cultivars produced in the region should also be examined.
\end{abstract}

$\mathrm{T}$ The U.S. craft beer industry continues to grow. According to the Brewers Association, an industry body representing small- and medium-size brewers, sales by craft brewers grew at a rate of $4 \%$ in 2018

Received for publication 2 Sept. 2020. Accepted for publication 12 June 2021

Published online 20 July 2021.

${ }^{1}$ Agriculture Research Station, Virginia State University, Petersburg, VA 23906

${ }^{2}$ Department of Horticulture, Virginia Tech, Blacksburg, VA 24061

${ }^{3}$ Mountain Horticultural Crops Research \& Exten sion Center, North Carolina State University, 455 Research Drive, Mills River, NC 28759

This work was supported by the U.S. Department of Agriculture-National Institute of Food and Agriculture-1890 Institution Capacity Building Grant (Agreement 2015-38821-24384).

This is a Virginia State University Agricultural Research Publication 373.

We thank Anwar Hamama and Zaid Abraha-Eyob (Virginia State University-Agriculture Research Station Common Laboratory) and Ken Hurley (Virginia Tech Enology Laboratory) for hop quality analysis.

L.K.R. is the corresponding author. E-mail: lrutto@ vsu.edu.

This is an open access article distributed under the CC BY-NC-ND license (https://creativecommons. org/licenses/by-nc-nd/4.0/).

https://doi.org/10.21273/HORTTECH04727-20 to reach $13.2 \%$ of the U.S. beer market by volume, even as overall beer sales continue to decline (Brewers Association, 2019). This was equivalent to about $\$ 28$ billion in value, accounting for $24 \%$ of the $\$ 114$ billion U.S. beer market.

Virginia and North Carolina, respectively with 236 and $291 \mathrm{craft}$ breweries in 2018, are well represented in the industry (Brewers Association, 2019). Regionally, the craft beer industry has sparked grower interest in agricultural products used in brewing, including hops (Humulus lupulus), a key flavoring agent used to lend bitterness and aroma to beer (Siegle and Scoggins, 2017, 2018). However, most of the landowners in question have no prior experience with hop production and postharvest handling and processing, and it has fallen on respective land-grant universities to allocate resources and develop programs to address these key issues.

In the United States, hops are produced almost entirely in the Pacific Northwest United States (PNW) under conditions that are markedly different from those common to the Mid-Atlantic United States. The three U.S. states, Washington, Oregon, and Idaho, that accounted for more than $95 \%$ of harvested acreage in 2019 (Hop Growers of America, 2020) are situated at higher latitudes $\left(44-47^{\circ} \mathrm{N}\right)$ relative to Mid-Atlantic states $\left(35-37^{\circ} \mathrm{N}\right)$ and their growing season is generally characterized by lower relative humidity and less rainfall. Thus, agronomic practices recommended for the PNW may not be applicable to the Mid-Atlantic United States. Furthermore, hop producers face a number of economically important pests and diseases (Mahaffee et al., 2009) of which downy mildew (Psendoperonospora humuli) and powdery mildew (Podosphaera macularis), both influenced by climatic factors such as temperature, relative humidity, and leaf wetness, would be of particular concern in Mid-Atlantic United States.

Therefore, the objectives of our work were to evaluate agronomic performance and to observe pest and disease interactions in the selected hop cultivars as influenced by prevailing weather and other production factors in Virginia. Here, we report data of five cultivars (Cascade, Chinook, Newport, Nugget, and Zeus) grown at three sites representing different agroecological zones in the Commonwealth of Virginia.

\begin{tabular}{llll}
\hline $\begin{array}{l}\text { Units } \\
\text { To convert U.S. to SI, } \\
\text { multiply by }\end{array}$ & U.S. unit & SI unit & $\begin{array}{l}\text { To convert SI to U.S., } \\
\text { multiply by }\end{array}$ \\
\hline 0.4047 & acre $(\mathrm{s})$ & $\mathrm{ha}$ & $2.471 \mathrm{l}$ \\
29.5735 & $\mathrm{fl} \mathrm{oz}$ & $\mathrm{mL}$ & 0.0338 \\
0.3048 & $\mathrm{ft}$ & $\mathrm{m}$ & 3.2808 \\
25.4 & inch $(\mathrm{es})$ & $\mathrm{mm}$ & 0.0394 \\
1.1209 & $\mathrm{lb} / \mathrm{acre}$ & $\mathrm{kg} \cdot \mathrm{ha}^{-1}$ & 0.8922 \\
1 & $\mathrm{meq} / 100 \mathrm{~g}$ & $\mathrm{cmol} \cdot \mathrm{kg}^{-1}$ & 1 \\
28.3495 & $\mathrm{Oz}$ & $\mathrm{g}$ & 0.0353 \\
1 & $\mathrm{ppm}$ & $\mu \mathrm{\mu g} \cdot \mathrm{g}^{-1}$ & 1 \\
0.001 & $\mathrm{ppm}$ & $\mathrm{mL} / 100 \mathrm{~g}$ & 1000 \\
$\left({ }^{\circ} \mathrm{F}-32\right) \div 1.8$ & ${ }^{\circ} \mathrm{F}$ & ${ }^{\circ} \mathrm{C}$ & $\left({ }^{\circ} \mathrm{C} \times 1.8\right)+32$
\end{tabular}




\section{Materials and methods}

Experimental sites. The three sites where hop cultivar trials were conducted are Machipongo, VA (lat. $37^{\circ} 39^{\prime} \mathrm{N}$, long. $75^{\circ} 89^{\prime} \mathrm{W}$ ) in Northampton County on the eastern shore, the Virginia State University Randolph Research and Demonstration Farm (lat. $37^{\circ} 13^{\prime} \mathrm{N}$, long. $77^{\circ} 26^{\prime} \mathrm{W}$ ) in Chesterfield County, and Madison, VA (lat. $38^{\circ} 38^{\prime} \mathrm{N}$, long. $78^{\circ} 27^{\prime} \mathrm{W}$ ) in Madison County along the foothills of the Blue Ridge Mountains (Fig. 1). Soil type at the three sites are, respectively, a Bojac sandy loam (Typic Hapludults) in Northampton, a mixture of Norfolk fine sandy loam, Tetotum clay, and Myatt clay (Typic Kandiudults) in Chesterfield, and a mixture of Hiwassee and Llyod clay loams (Rhodic Kanbapludults) in Madison County.

SoIL ANALYsIs. Soil samples were collected at the beginning of each cropping season and analyzed for mineral content and chemical properties. Samples were air-dried then passed through a $2-\mathrm{mm}$ sieve in preparation for analysis. In the laboratory, soils were processed for measurement of elements including phosphorus $(\mathrm{P})$, potassium $(\mathrm{K})$, calcium $(\mathrm{Ca})$, magnesium $(\mathrm{Mg})$, zinc $(\mathrm{Zn})$, manganese $(\mathrm{Mn})$, copper $(\mathrm{Cu})$, iron $(\mathrm{Fe})$, and boron (B) by extraction in a Mehlich III solution following methods described by Mehlich (1984). Briefly, $2 \mathrm{~g}$ of soil per sample was mixed with $20 \mathrm{~mL}$ of Mehlich III solution and extracted by shaking for $5 \mathrm{~min}$ on a reciprocating mechanical shaker. After shaking, the suspension was filtered and analyzed for mineral content on an inductively coupled plasma-atomic emission spectrometer [ICP-AES (Prodigy High Dispersion ICP; Teledyne Instruments Leeman Laboratories, Hudson, NH)]. Chemical properties (buffer index, cation exchange capacity, acidity, and base saturation) were determined following standard procedures (Brown, 2011), whereas pH (1:1) was measured following methods published by the American Society of Agronomy (Thomas, 1996). Soil conditions at respective sites before plant establishment in 2016 are shown in Table 1.

Climate Data. Weather stations equipped with a rain gauge, and temperature, relative humidity, and leaf wetness sensors were installed at each site where cultivar trials were conducted. Except for rainfall, all other climate data were recorded at 30-min intervals using a datalogger (HOBO RX3000; Onset Computers, Bourne, MA) and downloaded remotely for processing. Temperature, relative humidity, and leaf wetness data were analyzed to determine the number of hours when thresholds for heightened hop susceptibility to downy and powdery mildew were met during the growing season.

Plant materials. Five hop cultivars (Cascade, Chinook, Newport, Nugget, and Zeus) were planted at respective sites in Spring 2016 using rooted cuttings purchased from Great Lakes Hops (Zeeland, MI). All three hop yards were on 18-ft-tall trellis systems with plant rows oriented in an east-west direction. Plant rows were spaced $10 \mathrm{ft}$ apart and plants $3.5 \mathrm{ft}$ apart within rows for a population of $\approx 1380$ plants/acre. At the beginning of each season, shoots were cut back until 15-20 Apr. with shoots emerging thereafter trained from 10 to 15 May onto coir twine suspended from the trellis and anchored along the row with twine clips. A V-shaped training system with two strings per plant and three shoots trained to each string was adopted. Fertilizer was applied at all three sites following recommendations made by Sirrine et al. (2010). Taking soil analysis results into consideration, $100 \mathrm{lb} /$ acre nitrogen $(\mathrm{N})$ was applied starting from 2017. The $\mathrm{N}$ was delivered in two splits: $50 \%$ after training in May, and the remainder when plants reached the top of

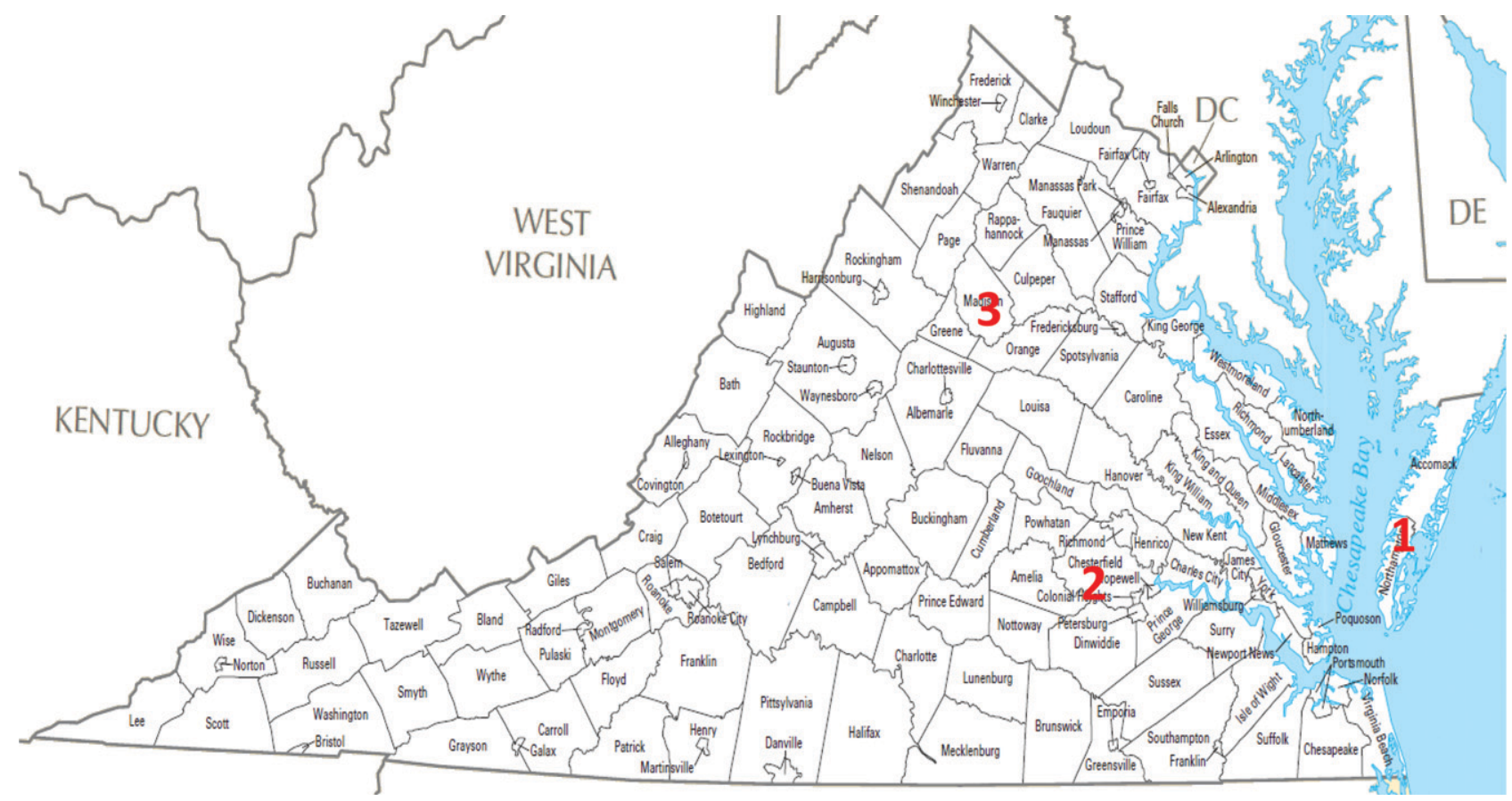

Fig. 1. Sites in Virginia where hop cultivar trials were conducted: 1 = Northampton County [Machipongo, VA $\left(\right.$ lat. $37^{\circ} 39^{\prime} \mathrm{N}^{\prime}$ long. $\left.75^{\circ} 89^{\prime} \mathrm{W}\right)$ ], 2 = Chesterfield County [Virginia State University Randolph Farm $\left(\right.$ lat. $37^{\circ} 13^{\prime} \mathrm{N}$, long. $\left.\left.^{\circ} 7^{\circ} 26^{\prime} \mathrm{W}\right)\right]^{\prime} 3=$ Madison County [Madison, VA (lat. $38^{\circ} 38^{\prime} \mathrm{N}$, long. $\left.78^{\circ} 27^{\prime} \mathrm{W}\right)$ ]. 
the trellis. The first $\mathrm{N}$ application was usually in the form of a compound fertilizer selected to also supply 20-30 $\mathrm{lb} /$ acre $\mathrm{P}$ and $80-150 \mathrm{lb} /$ acre $\mathrm{K}$.

In response to downy mildew pressure, the hop yard in Northampton County adopted a spray program involving application of a combination of copper hydroxide (Kocide 3000; Dupont, Wilmington, DE) and famoxadone/cymoxanil (Tanos, Dupont) followed by dimethomorph (Forum; BASF Corp., Florham Park, FL) on every row in 2-week intervals from May to August, for a total of 10,11 , and 10 sprays in 2017, 2018, and 2019, respectively. At the Chesterfield County hop yard, mefenoxam/copper hydroxide (Ridomil; Syngenta, Greensboro, NC) was applied once as a soil drench via the drip system before shoot training. During the season, cymoxanil (Curzate, Dupont) and aluminum tris (O-ethyl phosphonate) (Aliette; Bayer Crop Science, Research Triangle, NC) were applied in turns before a rain event for a total of 7,12 , and 8 applications in 2017,2018 , and 2019, respectively. At both sites, all products were applied following label recommendations and guidelines published for Virginia hop growers by Nita (2020). Additionally, beetle traps were used to control Japanese beetle (Popillia japonica) infestation at the Chesterfield County site. No sprays for pest and disease control were applied at the Madison County site, and none for pest control at Northampton. Irrigation was managed by individual hop yards according to need based on visual observation of the crop.

ExPERIMENTAL DESIGN. A randomized complete block design was adopted in this study. Each of the six contiguous rows with experimental plants were treated as randomly distributed blocks. Within each block were five 15-plant replicate panels, with each cultivar represented by three plants randomly distributed within the panel. Each panel was separated from the next by a 6 -ft buffer. For statistical purposes, within row means were treated as replicates resulting in a subject population of between four and six, depending on cultivar survival and uniformity.

SAMPLING AND SAMPLE PROCESSING. In July, petioles from an average of 20 mature leaves per cultivar were collected from each panel and pooled to obtain about 100 petioles per cultivar per block. The petioles grouped by block were put in labeled envelopes and dried in a convection oven at $72{ }^{\circ} \mathrm{C}$ to constant weight. Dried samples were ground with a Wiley mill to pass a $2-\mathrm{mm}$ sieve before transfer to the laboratory for mineral analysis. At cone maturity (August-September), bines were cut and transported to a central location where cones (female flowers) were separated from noncone biomass. At the Northampton site, cone separation was done using a mechanical harvester (Hopstar; Seaside Hops, Machipongo, VA), while a different unit (Hopster5P; Hopsharvester, Honeye, NY) was used at the Chesterfield site in 2017 and 2019, and at the Madison site in 2017. Cone separation was done manually at the Madison site in 2019. At the Chesterfield County site, cones harvested in 2017 were oven-dried at $130{ }^{\circ} \mathrm{F}$ to a moisture content of $10 \%$ to $12 \%$, while fresh samples were kept in frozen storage before analysis in 2019. Soil conditions at respective sites before planting in 2016 are shown in Table 1.

Plant analysis. In the laboratory, petiole subsamples were subjected to microwave digestion (Kuss, 1992) followed by filtration and centrifuging. Metal content in individual samples was determined using an ICP-AES as described in the U.S. Environmental Protection Agency (EPA) method 6010D (EPA, 2014).

Analyses of $\alpha$ and $\beta$ acid, and essential oil content in hop cones were done following methods published by the American Society of Brewing Chemists (ASBC). Briefly, $15 \mathrm{~g}( \pm 0.01)$ samples of ground cone biomass were transferred into 1000$\mathrm{mL}$ extraction bottles to which 300 $\mathrm{mL}$ toluene was added. The vessels were stoppered and shaken for $30 \mathrm{~min}$ on a rotary shaker. After $30 \mathrm{~min}$, samples were centrifuged at $450 \mathscr{g}_{n}$ for 5 min and allowed to settle for $10 \mathrm{~min}$ before a $5-\mathrm{mL}$ clear aliquot was drawn. Samples were diluted and absorbance determined using a spectrophotometer (ASBC, 2011). Absorbance readings were used to compute $\alpha$ and $\beta$ acid content in dry matter for the different samples using formulas provided by the ASBC. Total volumes of essential oil in 100-g cone samples were quantified after steam distillation. Oil samples were prepared for fractionation by mixing $900 \mu \mathrm{L}$ hexane containing $1 \%(\mathrm{v} / \mathrm{v}) 2$-octanol (internal standard) with $100 \mu \mathrm{L}$ hop oil. A $1 \mu \mathrm{L}$ sample of the $10 \%$ hop oil solution was injected into a gas chromatograph $(6890 \mathrm{~N}$; Agilent Technologies, Santa Clara, CA) equipped with a column (HP-INNOWax, Agilent Technologies) and flame ionization detector. Peaks were plotted on accompanying data acquisition software and individual oils identified by comparison against a reference chromatogram included with the methods (ASBC, 2011). Due to the high cost of analysis and significant volume of sample required, only material from the Chesterfield County site was processed for determination of $\alpha$ and $\beta$ acids, and essential oils.

STATISTICAL ANALYSIS. The PROC MIXED procedure (SAS/ STAT version 9.4 for Windows; SAS Institute, Cary, NC) was used to perform one-way analysis of variance (ANOVA) for disease index data, while two-way ANOVA was used to compare site/cultivar effects on hop mineral nutrition. Yield data were subjected to three-way ANOVA with season, site, and cultivar taken as independent variables. For all three analyses, mean separation was done using Tukey's honestly significant difference test $(P \leq 0.05)$ where significant differences were present. Cone quality data for material harvested in 2017 and 2019 from the Chesterfield site was compared between years (within cultivar) using Welch's unequal variances $t$ test $(P \leq 0.05)$.

\section{Results}

Growing conditions. Ambient temperatures recorded at the three sites during the growing season in 2017 were comparable to historical averages except in Madison County where monthly maximum and minimum temperatures were higher by $>1{ }^{\circ} \mathrm{C}$ in March, May, and July. In 2018, similar conditions were observed at the Chesterfield and Northampton County sites, while monthly minimum temperatures trended 1 to $3^{\circ} \mathrm{C}$ higher in Madison County. In 2019, temperature readings at all three sites were generally comparable to or higher than historical averages for most of the growing season (Table 2). Rainfall data shows that 2017 totals were lower than historical averages by $25-130 \mathrm{~mm}$ at all three sites (Fig. 2). The opposite was observed in 2018 when significantly 
Table 1. Soil test results before plant establishment in 2016 for three sites in Virginia where hop cultivar trials were conducted.

\begin{tabular}{|c|c|c|c|}
\hline & \multicolumn{3}{|c|}{ Site $^{\mathrm{y}}$} \\
\hline & Northampton & Chesterfield & Madison \\
\hline \multicolumn{4}{|l|}{ Mineral content ${ }^{\mathrm{z}}$} \\
\hline Phosphorus (lb/acre) & 164 & 131 & 39 \\
\hline Potassium [K (lb/acre $)]$ & 115 & 336 & 407 \\
\hline Calcium $[\mathrm{Ca}$ (lb/acre) $]$ & 542 & 1235 & 2851 \\
\hline Magnesium $[\mathrm{Mg}$ (lb/acre) $]$ & 122 & 197 & 972 \\
\hline Zinc $(\mathrm{ppm})$ & 2.3 & 3.6 & 4.4 \\
\hline Manganese (ppm) & 20.0 & 7.9 & 9.5 \\
\hline Copper $(\mathrm{ppm})$ & 0.5 & 1.3 & 0.2 \\
\hline Iron $(\mathrm{ppm})$ & 83.4 & 65.7 & 8.8 \\
\hline Boron (ppm) & 0.3 & 0.3 & 0.8 \\
\hline \multicolumn{4}{|l|}{ Chemical properties } \\
\hline $\mathrm{pH}$ & 6.3 & 6.7 & 7.1 \\
\hline Buffer index & 6.9 & 6.4 & 6.6 \\
\hline $\operatorname{CEC}(\mathrm{meq} / 100 \mathrm{~g})^{\mathrm{x}}$ & 4.5 & 4.4 & 11.6 \\
\hline Acidity (\%) & 10 & 1.1 & 0.0 \\
\hline Base saturation (\%) & 90 & 98.9 & 100 \\
\hline $\mathrm{Ca}^{2+}$ saturation $(\%)$ & 60 & 70.5 & 61.1 \\
\hline $\mathrm{Mg}^{2+}$ saturation $(\%)$ & 23 & 18.6 & 34.4 \\
\hline $\mathrm{K}^{+}$saturation $(\%)$ & 7.0 & 9.8 & 4.5 \\
\hline
\end{tabular}

higher rainfall was recorded at the Chesterfield and Madison County sites. Respectively, total rainfall was 202, 474 , and $713 \mathrm{~mm}$ higher than historical averages at the Northampton,

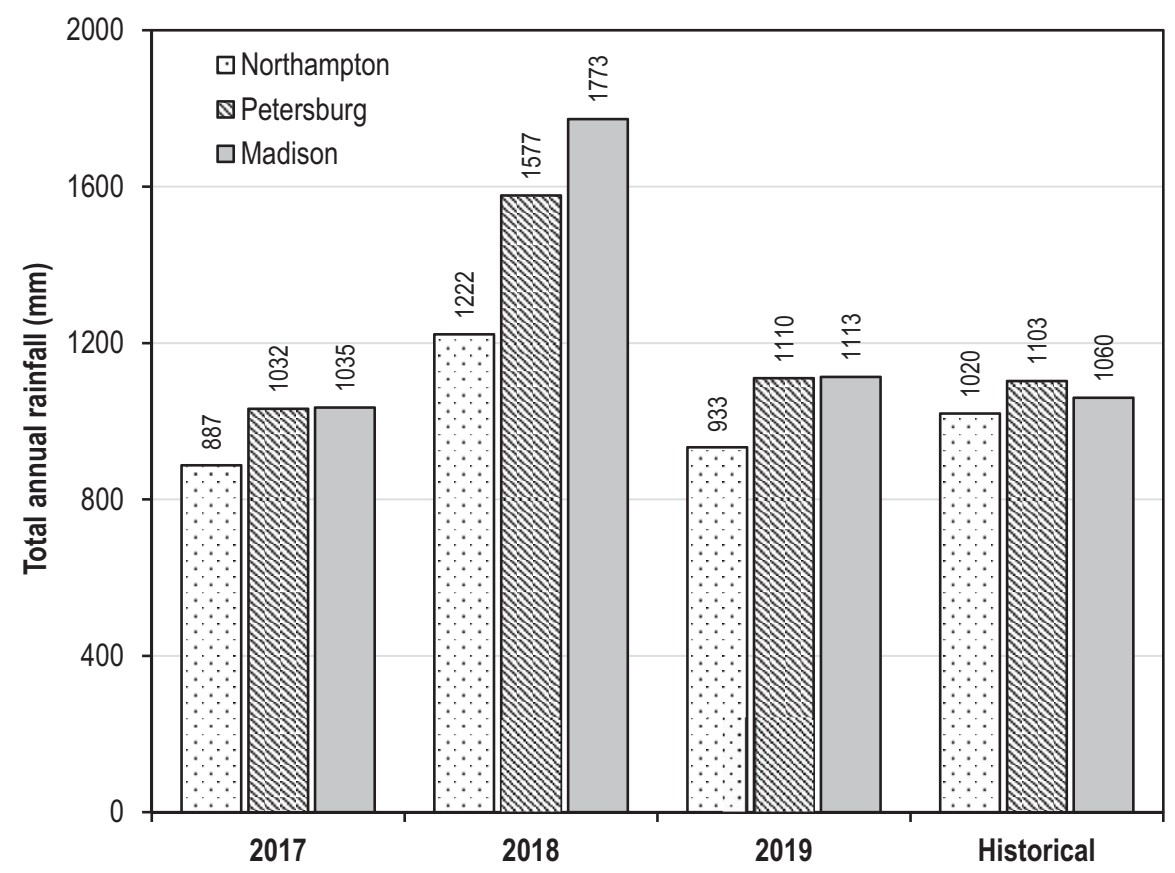

Fig. 2. Total annual $(2017,2018,2019)$ and historical (1970-2000) rainfall data for three Virginia sites where hop cultivar trials were conducted: Northampton County [Machipongo, VA (lat. $37^{\circ} 39^{\prime} \mathrm{N}$, long. $75^{\circ} 89^{\prime} \mathrm{W}$ )], Chesterfield County [Virginia State University Randolph Farm (lat. $37^{\circ} 13^{\prime} \mathrm{N}$, long. $77^{\circ} 26^{\prime} \mathrm{W}$ )], and Madison County [Madison, VA (lat. $38^{\circ} 38^{\prime} \mathrm{N}$, long. $78^{\circ} 27^{\prime} \mathrm{W}$ )]; $1 \mathrm{~mm}=0.0394$ inch. both Chesterfield and Madison County sites (Fig. 2).

Disease IndicATORs. Data derived based on weather indicators for downy (temperature and leaf wetness) and powdery mildew (temperature and relative humidity) infectivity on hops are presented in Table 3 . Results show that starting from April, thresholds for disease outbreak were met at all sites (except Madison in 2018). Conditions conducive for infection by both mildews were also shown to be present throughout the growing season. Within season, potential for incidence of downy mildew was found to be highest at all three sites in May and June, and later in the season in August and September. Among sites, Madison County reported a longer duration (stretching into July) when conditions were favorable for the outbreak of downy mildew, and when compared with the Northampton and Chesterfield sites, recorded the highest number of hours favorable to downy mildew infection from May to September (Table 3). Statistical comparison of within-season (March-October) monthly means found no significant difference in conditions favoring downy mildew among the three sites in 2017 and 2019, with the Madison County site recording significantly more hours when conditions were conducive for downy mildew infection in 2018. For powdery mildew, hop susceptibility to the disease was observed to be generally lower at the Chesterfield County site over the 3-year period (Table 3).

Plant nutrition. Mineral nutrition in 2017 varied among cultivars and site. For $\mathrm{N}$, content was highest in 'Newport' samples from the Chesterfield site and lowest in 'Nugget' samples from Northampton. Overall, N content was marginally higher in samples from Chesterfield and Madison, but no clear cultivarassociated trend was evident. Among other macronutrients, $\mathrm{P}$ was significantly $(P \leq 0.05)$ higher in 'Zeus' samples from the Chesterfield site and lowest in 'Cascade' samples from Madison, while $\mathrm{K}$ content was highest, and lowest in 'Zeus' samples from the Madison and Northampton sites, respectively. Similarly, $\mathrm{Ca}$ and $\mathrm{Mg}$ content were highest in 'Newport' and 'Cascade' samples from Chesterfield and Northampton, respectively. 
Table 2. Mean, maximum ( $\max$ ), and minimum (min) temperature during the growing season at three sites in Virginia where hop cultivar trials were conducted.

\begin{tabular}{|c|c|c|c|c|c|c|c|c|c|c|}
\hline \multirow[b]{2}{*}{ Yr } & \multirow[b]{2}{*}{ Month } & \multicolumn{3}{|c|}{ Northampton $^{\mathrm{z}}$} & \multicolumn{3}{|c|}{ Chesterfield } & \multicolumn{3}{|c|}{ Madison } \\
\hline & & Mean & $\operatorname{Max}$ & Min & Mean & Max & Min & Mean & Max & Min \\
\hline & & \multicolumn{9}{|c|}{$\operatorname{Temp}\left({ }^{\circ} \mathbf{C}\right)^{\mathbf{y}}$} \\
\hline \multirow[t]{7}{*}{2017} & Mar. & 8 & 13 & 4 & 9 & 15 & 2 & 7 & 14 & 0 \\
\hline & Apr. & 17 & 21 & 13 & 18 & 25 & 11 & 15 & 22 & 9 \\
\hline & May & 18 & 22 & 15 & 19 & 25 & 13 & 17 & 23 & 12 \\
\hline & June & 23 & 27 & 19 & 23 & 29 & 17 & 23 & 29 & 16 \\
\hline & July & 27 & 30 & 23 & 24 & 28 & 16 & 26 & 32 & 19 \\
\hline & Aug. & 24 & 28 & 20 & 25 & 30 & 20 & 23 & 29 & 17 \\
\hline & Sept. & 22 & 25 & 18 & 22 & 27 & 16 & 20 & 26 & 14 \\
\hline \multirow[t]{7}{*}{2018} & Mar. & 6 & 10 & 2 & 7 & 12 & 1 & 7 & 16 & 1 \\
\hline & Apr. & 12 & 17 & 7 & 13 & 20 & 6 & 11 & 18 & 4 \\
\hline & May & 21 & 26 & 17 & 23 & 29 & 17 & 21 & 27 & 15 \\
\hline & June & 24 & 28 & 20 & 25 & 30 & 20 & 23 & 28 & 18 \\
\hline & July & 25 & 29 & 21 & 25 & 31 & 20 & 24 & 30 & 19 \\
\hline & Aug. & 26 & 30 & 22 & 26 & 32 & 21 & 25 & 30 & 19 \\
\hline & Sept. & 25 & 28 & 22 & 24 & 28 & 20 & 22 & 27 & 18 \\
\hline \multirow[t]{7}{*}{2019} & Mar. & 7 & 12 & 3 & 8 & 15 & 1 & 6 & 12 & -1 \\
\hline & Apr. & 21 & 20 & 11 & 16 & 23 & 10 & 14 & 20 & 7 \\
\hline & May & 15 & 25 & 17 & 22 & 29 & 16 & 20 & 26 & 14 \\
\hline & June & 24 & 28 & 19 & 24 & 29 & 18 & 22 & 28 & 16 \\
\hline & July & 26 & 31 & 22 & 27 & 33 & 21 & 26 & 32 & 20 \\
\hline & Aug. & 25 & 29 & 21 & 26 & 32 & 20 & 24 & 30 & 17 \\
\hline & Sept. & 23 & 27 & 19 & 24 & 31 & 18 & 23 & 30 & 16 \\
\hline
\end{tabular}

${ }^{\mathrm{z}}$ Northampton County [Machipongo, VA (lat. $37^{\circ} 39^{\prime} \mathrm{N}$, long. $75^{\circ} 89^{\prime} \mathrm{W}$ )], Chesterfield County [Virginia State University Randolph Farm (lat. $37^{\circ} 13^{\prime} \mathrm{N}$, long. $77^{\circ} 26^{\prime} \mathrm{W}$ )], Madison County [Madison, VA (lat. $38^{\circ} 38^{\prime} \mathrm{N}$, long. $\left.\left.78^{\circ} 27^{\prime} \mathrm{W}\right)\right]$.

${ }^{\mathrm{y}}\left({ }^{\circ} \mathrm{C} \times 1.8\right)+32={ }^{\circ} \mathrm{F}$. There needs to be more space between the table footnotes and the main text

There was less variation in sulfur $(S)$ nutrition with no significant difference in content between 'Cascade' and 'Newport' samples from Chesterfield, and 'Nugget' samples from Chesterfield and Madison on the higher end, and the rest of the samples, with 'Zeus' grown at the Northampton site recording the lowest petiole $S$ content. Among cultivar and site associated trends, Ca concentration was lowest in 'Zeus' at all sites while on average, $\mathrm{N}$, $\mathrm{P}$, and $\mathrm{K}$ were highest in Chesterfield, and sodium $(\mathrm{Na})$ in Northampton. Site and cultivar, and their interaction were found to be highly significant as independent determinants of hop nutrition (Table 4).

Compared against reference sufficiency data published by Sirrine (2016), petiole content of most mineral elements fell within ranges considered adequate for hops. Exceptions were observed for $S$ where content in 'Chinook', 'Newport', 'Nugget', and 'Zeus' samples from Northampton. 'Chinook' samples from Chesterfield, and 'Cascade', 'Chinook', and 'Zeus' samples from Madison were below the recommended minimum. The same applied to Zn content in 'Nugget' and 'Zeus' samples from Northampton, and $\mathrm{Cu}$ in samples from all cultivars grown at the Chesterfield and Madison sites. On the other hand, Mn content in samples from all cultivars was generally higher than the recommended range $(25-150 \mathrm{ppm})$ at all three sites (Table 4).

CONE YIELD. Among cultivars, 'Zeus' was the highest yielding followed by Cascade and Nugget, with Newport being the least productive (Table 5 ). When compared by season it is evident that yields were generally higher in 2017 than in 2019, and by site, in Northampton relative to Chesterfield and Madison. Yield in 'Zeus' was significantly $(P \leq 0.05)$ higher at Northampton than at the other two sites in 2017 and 2019, and lowest in Madison in 2019. Similarly, yield in 'Chinook' was significantly higher in 2017 at the Chesterfield site and lowest in Northampton in 2019, where it failed to yield a crop. With the exception of 'Chinook', all cultivars at the Northampton site recorded significantly higher yields in 2017 than in 2019, while Cascade and Nugget performed well in both seasons (Table 5). Threeway ANOVA for fixed effects showed that season, site, and cultivar were highly significant with respect to yield. Interactions within and among the three variables (season, site, and cultivar) were similarly highly significant (Table 5).

Cone Quality. Quality attributes ( $\alpha$ and $\beta$ acids, and essential oils) are presented only for crop harvested from the Chesterfield site in 2017 and 2019. Comparisons between the 2 years show that $\alpha$ and $\beta$ acid, and essential oil content was significantly $(P \leq 0.05)$ higher in 'Cascade' samples from the 2019 season relative to 2017. The opposite was observed in 'Zeus' where $\beta$ acid and essential oil content were significantly higher in 2017 than in 2019 . There was no significant change between years in 'Zeus' and 'Chinook' $\alpha$ acid content, and in 'Chinook' $\beta$ acid and essential oil content. Out of the five cultivars, 'Newport' and 'Nugget' yields in 2019 were too low to justify sampling and quality analysis (Table 6).

Fractionation of essential oils from cultivars harvested in 2017 and 2019 exposed between-year differences in some constituents (Table 7). In 'Cascade', myrcene and farnesene contents were significantly $(P \leq 0.05)$ higher in 2019 than in 2017, whereas geraniol was higher in 2017 than in 2019. Farnesene, linalool, and geraniol were higher in 'Chinook' in 2017, while 'Zeus' samples from the same year recorded significantly higher myrcene, farnesene, and linalool. There were no differences between years in humulene and caryophylene content for the three cultivars, and in linalool, myrcene, and geraniol in 'Cascade', 'Chinook', and 'Zeus', respectively. 'Newport' and 'Nugget' yields were too low in 2019 to justify sampling and quality analysis and no statistical comparisons are presented for these cultivars (Table 7).

\section{Discussion}

The project to evaluate hop cultivars at three Virginia sites was motivated by a general lack of agronomic information for a crop that is gaining attention in the eastern United States. Findings in this study conducted over 3 years (2017-19) show that a 


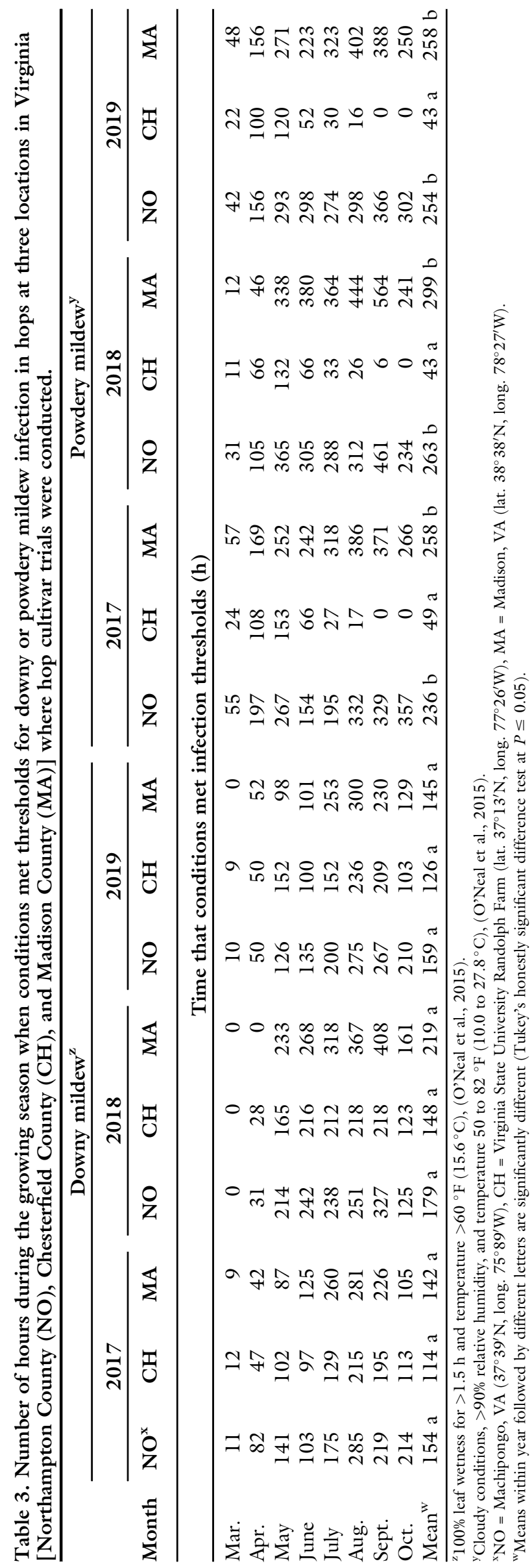

majority of the five cultivars tested faced significant challenges at the three sites. In particular, results from the 2018 growing season suggest that unseasonably high rainfall-increasingly common in the region-can increase pest and disease pressure to unsustainable levels, especially in the absence of adequate pest and disease control measures. It has been reported that hops will respond positively to increasing rainfall or irrigation where moisture is limiting (Donner et al., 2020), but beyond a certain point, additional precipitation will compound disease problems. Johnson et al. (1983) observed that a wet April/May coupled with above-normal temperatures in early spring favored downy mildew development. Skotland and Johnson (1983) also report that downy mildew was a factor in the decline of hop production in New York, Wisconsin, and the coastal areas of California, and that its occurrence in the high rainfall areas of western Oregon and Washington was responsible for the demise of susceptible cultivars in the 1930s.

Our results show that conditions favorable to hop downy and powdery mildew exist throughout the growing season at the three Virginia sites where cultivar trials were conducted. In 2018, excessive rainfall accounted for a host of challenges including growth-limiting poor drainage and higher insect, pest, and weed pressure that, together with downy mildew, were responsible for the crop failure reported. A similar observation was made by Judd (2018) for cultivar trials conducted at the Virginia Tech campus in Blacksburg where downy mildew, even with repeated spraying, was responsible for the loss of cultivars including Mt. Hood, Sorachi Ace, and Southern Brewer. At the three sites for which data are reported in this study, and in practically all Virginia hop yards, downy mildew is now systemic among susceptible cultivars. However, despite the prevailing conditions, we have not observed powdery mildew in Virginia except on 'Zeus' under greenhouse conditions, but S.T. Massie (personal communication) has reported its incidence in one North Carolina hop yard. Limited incidence of powdery mildew in the region may be due to lower $\mathrm{N}$ fertilization relative to the PNW as suggested by D.H. 


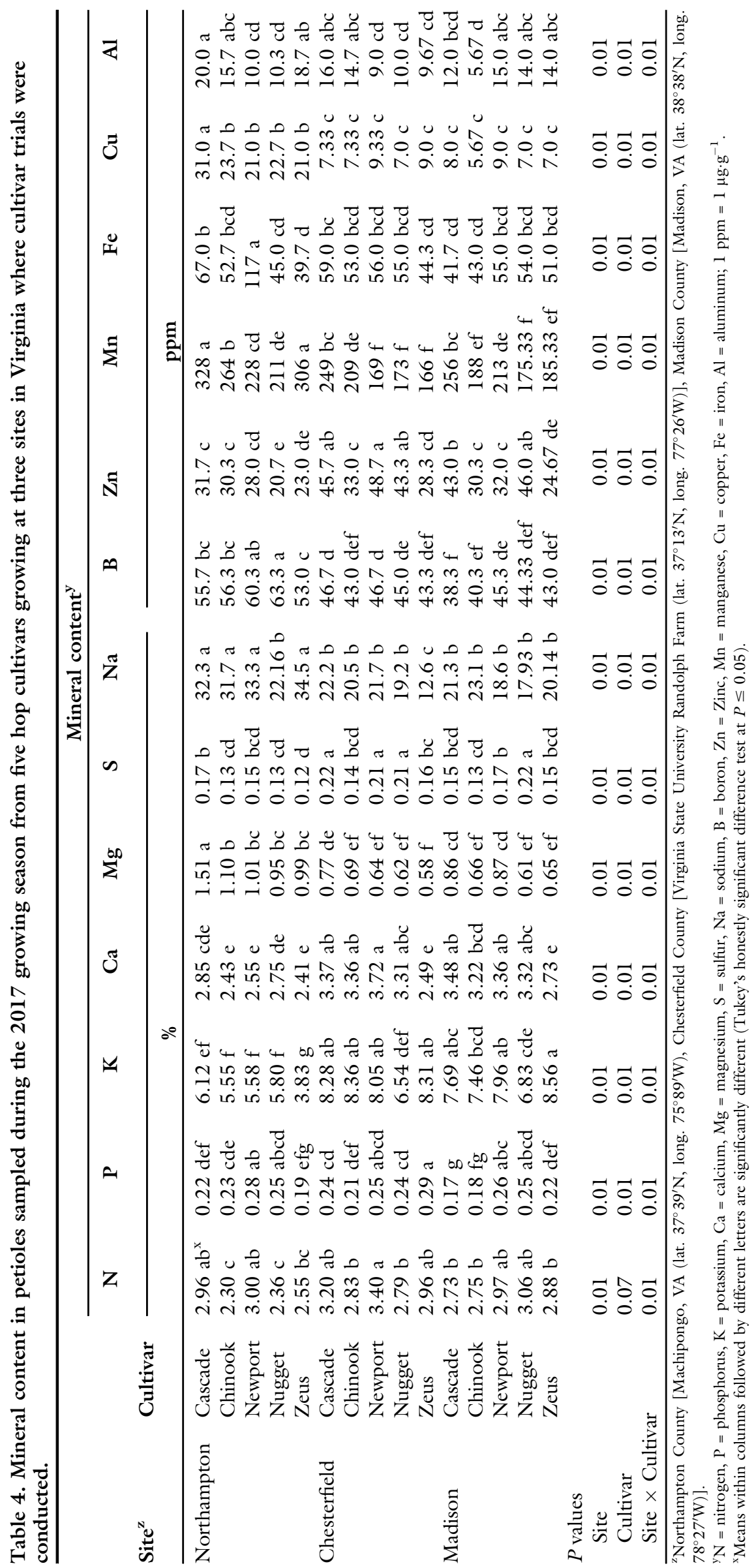

Gent (personal communication) and according to findings by Iskra et al. (2019). Other diseases of economic importance encountered in Virginia and North Carolina include fusarium canker caused by Fusarium sambucinum (Judd, 2018; S.T. Massie, personal communication) and red crown rot (Phomopsis tuberivora) in heavy soils (S.T. Massie, personal communication). Among pests, the Japanese beetle caused significant damage at the Virginia Tech (Judd, 2018) and Virginia State University hop yards in 2017 and is a recurring challenge. Pests of minor concern include red spider mite (Tetranychus urticae), hop aphid (Phorodon humuli), hop looper (Hypena humuli), and European corn borer (Ostrinia nubilalis).

According to Neve (1991) cultural practices, other than effective control of pests and diseases, may not be as important as the environment in determining hop $\alpha$ and $\beta$ acid content. There is general consensus that environmental conditions are important determinants of cone chemistry. Variously, ambient temperature during the growing season (Smith, 1970; Thomas, 1980; Zattler and Jehl, 1962), insolation (Méneret and Svinareff, 1955, 1956; Zattler, 1960), and amount of rainfall during maturation (Méneret and Svinareff, 1955, 1956) have been found to influence $\alpha$ acid content in hop cones. However, none of these correlations could reliably predict hop quality on their own, leading to the proposition that final $\alpha$ acid content may rest on interactions among weather factors affecting cone weight during flowering, number of resin glands per cone, resin gland size, and percentage of resin in the glands (Thomas and Darby, 1984). This proposition is corroborated by more recent research reports; e.g., on the effects of temperature, rainfall, and solar radiation on $\alpha$ acid accumulation in the cultivar Aurora (Srečec et al., 2008), drought/excessive moisture on yield and $\alpha$ acid content in Saaz (Potop, 2014), and weather, irrigation, and plant age on yield and $\alpha$ acid content in the Czech cultivars Saaz, Sladek, Premiant, and Agnus (Donner et al., 2020).

Quality data ( $\alpha$ and $\beta$ acids, and essential oil content) for hops grown at the Chesterfield County site not only differed between 2017 and 
Table 5. Comparisons of computed yield per hectare by weight in 2017 and 2019 from five hop cultivars grown at three Virginia locations.

\begin{tabular}{|c|c|c|c|c|c|c|c|c|}
\hline \multirow[b]{3}{*}{ Site $^{\mathrm{z}}$} & \multirow[b]{3}{*}{$\mathrm{Yr}^{\mathrm{y}}$} & \multicolumn{7}{|c|}{ Cultivar } \\
\hline & & Cascade & & Chinook & & Nugget & Newport & Zeus \\
\hline & & \multicolumn{7}{|c|}{ Yield $\left(\mathrm{kg} \cdot \mathrm{ha}^{-1} \text { dry wt }\right)^{\mathrm{x}}$} \\
\hline \multirow[t]{2}{*}{ Northampton } & 2017 & $278 \mathrm{a}^{\mathrm{w}}$ & & $131 \mathrm{~b}$ & & $275 \mathrm{a}$ & $85 \mathrm{a}$ & 465 a \\
\hline & 2019 & $130 \mathrm{~cd}$ & & $0 \mathrm{~d}$ & & $113 \mathrm{c}$ & $0 \mathrm{c}$ & $400 \mathrm{~b}$ \\
\hline \multirow[t]{2}{*}{ Chesterfield } & 2017 & $246 \mathrm{a}$ & & $176 \mathrm{a}$ & & $113 \mathrm{c}$ & $33 \mathrm{~b}$ & $203 \mathrm{c}$ \\
\hline & 2019 & $93 \mathrm{~d}$ & & $54 \mathrm{c}$ & & $0 \mathrm{~d}$ & $0 \mathrm{c}$ & $145 \mathrm{~cd}$ \\
\hline \multirow[t]{2}{*}{ Madison } & 2017 & $160 \mathrm{bc}$ & & $128 \mathrm{~b}$ & & $174 \mathrm{~b}$ & $0 \mathrm{c}$ & $169 \mathrm{~cd}$ \\
\hline & 2019 & $198 \mathrm{~b}$ & & $40 \mathrm{c}$ & & $156 \mathrm{~b}$ & $0 \mathrm{c}$ & $130 \mathrm{~d}$ \\
\hline \multicolumn{2}{|l|}{ Statistics $^{\mathrm{v}}$} & \multicolumn{3}{|c|}{ Num df } & Den df & & $\mathbf{F}$ & $P$ value \\
\hline \multicolumn{2}{|l|}{ Year } & \multicolumn{3}{|c|}{1} & 120 & & 703.32 & 0.01 \\
\hline \multicolumn{2}{|l|}{ Site } & \multicolumn{3}{|c|}{2} & 120 & & 302.67 & 0.01 \\
\hline \multicolumn{2}{|l|}{ Cultivar } & \multicolumn{3}{|c|}{4} & 120 & & 721.99 & 0.01 \\
\hline \multicolumn{2}{|l|}{ Year $\times$ Site } & \multicolumn{3}{|c|}{2} & 120 & & 97.78 & 0.01 \\
\hline \multicolumn{2}{|l|}{ Year $\times$ Cultivar } & \multicolumn{3}{|c|}{4} & 120 & & 21.83 & 0.01 \\
\hline \multicolumn{2}{|l|}{ Site $\times$ Cultivar } & \multicolumn{3}{|c|}{8} & 120 & & 162.24 & 0.01 \\
\hline \multicolumn{2}{|c|}{ Year $\times$ Site $\times$ Cultivar } & & 8 & & 120 & & 13.14 & 0.01 \\
\hline \multicolumn{9}{|c|}{ 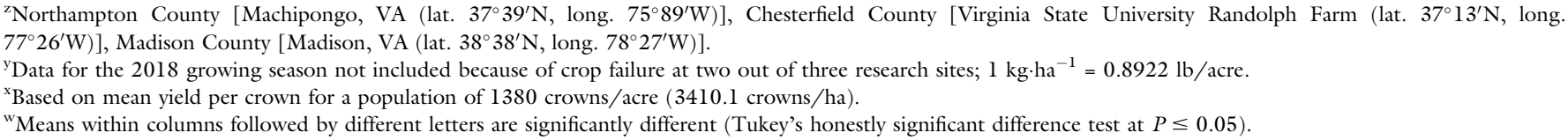 } \\
\hline
\end{tabular}

2019, they were found to be much lower than published ranges (Yakima Chief Hopunion, 2016) for each cultivar. We believe the lower values recorded in 2017 may have been influenced less by growing conditions than unsatisfactory postharvest handling (excessive drying and delayed cold storage), particularly for 'Cascade', which is rated as having very poor storability. In 2019, fresh samples were kept in frozen storage until analysis, and quality data for the three cultivars shows that Cascade samples from this season are the only ones that met the lower threshold of the published $\alpha$ acid range. At the Virginia Tech hop yard, quality data for 'Cascade' and 'Nugget' were within published ranges for the 2017 crop, but similarly lower than expected $\alpha$ and $\beta$ acid content was reported for some of the cultivars tested (Judd, 2018). With the

Table 6. Cone quality attributes for the 2017 and 2019 harvest from five hop cultivars grown at the Virginia State University Randolph Farm (lat. $37^{\circ} 13^{\prime} \mathrm{N}$, long. $\left.77^{\circ} 26^{\prime} \mathrm{W}\right)$.

\begin{tabular}{ccccc}
\hline Cultivar & Yr & $\boldsymbol{\alpha}$-acids (\%) & $\boldsymbol{\beta}$-acids (\%) & Essential oil $(\mathbf{m L} / \mathbf{1 0 0 ~ g})^{\mathbf{z}}$ \\
\hline Cascade & 2017 & $1.32 \mathrm{~b}^{\mathrm{y}}$ & $1.76 \mathrm{~b}$ & $0.23 \mathrm{~b}$ \\
& 2019 & $5.04 \mathrm{a}$ & $4.52 \mathrm{a}$ & $0.77 \mathrm{a}$ \\
$P$ value & & 0.01 & 0.02 & 0.01 \\
Chinook & 2017 & $5.19 \mathrm{a}$ & $1.39 \mathrm{a}$ & $0.59 \mathrm{a}$ \\
& 2019 & $6.71 \mathrm{a}$ & $1.89 \mathrm{a}$ & $0.72 \mathrm{a}$ \\
$P$ value & & 0.23 & 0.09 & 0.12 \\
Newport & 2017 & 2.90 & 1.48 & 0.54 \\
& 2019 & - & - & - \\
Nugget & 2017 & 7.79 & 1.71 & 0.61 \\
& 2019 & - & - & - \\
Zeus & 2017 & $5.07 \mathrm{a}$ & $1.22 \mathrm{~b}$ & $0.37 \mathrm{~b}$ \\
& 2019 & $5.66 \mathrm{a}$ & $2.84 \mathrm{a}$ & $0.51 \mathrm{a}$ \\
$P$ value & & 0.52 & 0.03 & 0.04 \\
\hline
\end{tabular}

${ }^{\mathrm{z}} 1 \mathrm{~mL} / 100 \mathrm{~g}=10,000 \mathrm{ppm}$.

${ }^{y}$ Means within cultivar followed by different letters are significantly different (Welch's unequal variances $t$ test at $P \leq 0.05$ ). exception of 'Newport', the hop cultivars we tested are considered dual use (bittering/aroma) and the lower than average essential oil content in all cultivars in 2017 and in Chinook and Zeus in 2019 is a source of concern. Overall, there is not yet enough data to gauge environmental effects on quality attributes of common commercial cultivars grown in Mid-Atlantic United States. However, the negative correlation between $\alpha$-acid content and high summer temperatures (Donner et al., 2020) on the one hand and excessive rainfall (Potop, 2014) on the other, coupled with observed, cultivar-specific, inhibition of photosynthetic activity above certain temperature thresholds (Eriksen et al., 2020) call for further cultivar evaluation for quality and overall performance.

As expected, yields were much lower than those realized in the northern regions including the PNW where days are longer during the summer and environmental conditions are more suited to hop culture. For example, our highest yield of $465 \mathrm{~kg} \cdot \mathrm{ha}^{-1}$ in 2017 from 'Zeus' grown in Northampton County was $45 \%$ less than projected yield for Michigan hops in the second year after planting (Sirrine 
Table 7. Constituents of essential oil extracted from five hop cultivars grown at the Virginia State University Randolph Farm (lat. $37^{\circ} 13^{\prime} \mathrm{N}$, long. $77^{\circ} 26^{\prime} \mathrm{W}$ ) for the 2017 and 2019 harvest.

\begin{tabular}{|c|c|c|c|c|c|c|c|}
\hline \multirow[b]{2}{*}{ Cultivar } & \multirow[b]{2}{*}{ Yr } & Myrcene & Humulene & Caryophyllene & Farnesene & Linalool & Geraniol \\
\hline & & \multicolumn{6}{|c|}{$\%$ of total essential oil } \\
\hline Cascade & 2017 & $28.3 \mathrm{~b}^{\mathrm{z}}$ & $29.5 \mathrm{a}$ & $11.4 \mathrm{a}$ & $1.13 \mathrm{~b}$ & $0.32 \mathrm{a}$ & $0.30 \mathrm{a}$ \\
\hline$P$ value & & 0.01 & 0.20 & 0.25 & 0.02 & 0.38 & 0.03 \\
\hline \multirow[t]{2}{*}{ Chinook } & 2017 & $24.0 \mathrm{a}$ & $27.2 \mathrm{a}$ & $11.0 \mathrm{a}$ & $2.35 \mathrm{a}$ & $0.72 \mathrm{a}$ & $0.32 \mathrm{a}$ \\
\hline & 2019 & $21.4 \mathrm{a}$ & $23.5 \mathrm{a}$ & $10.1 \mathrm{a}$ & $0.30 \mathrm{~b}$ & $0.28 \mathrm{~b}$ & $0.15 \mathrm{~b}$ \\
\hline Newport & 2019 & - & - & - & - & - & - \\
\hline \multirow[t]{2}{*}{ Nugget } & 2017 & 43.3 & 18.3 & 8.16 & 0.60 & 1.39 & 0.04 \\
\hline & 2019 & - & - & - & - & - & - \\
\hline \multirow[t]{2}{*}{ Zeus } & 2017 & $54.1 \mathrm{a}$ & $13.3 \mathrm{a}$ & $8.49 \mathrm{a}$ & $0.92 \mathrm{a}$ & $0.81 \mathrm{a}$ & $0.17 \mathrm{a}$ \\
\hline & 2019 & $27.2 \mathrm{~b}$ & $11.0 \mathrm{a}$ & $6.06 \mathrm{a}$ & $0.21 \mathrm{~b}$ & $0.28 \mathrm{~b}$ & $0.12 \mathrm{a}$ \\
\hline
\end{tabular}

${ }^{\mathrm{z}}$ Means within cultivar followed by different letters are significantly different (Welch's unequal variances $t$ test at $P \leq 0.05$ ).

et al., 2014). Furthermore, owing to the environmental setbacks of 2018, we did not observe the gradual increase in yield commonly associated with yard maturation. However, other than 'Newport', which failed to establish at all three sites, the plantings persist, and yields have shown signs of improvement in 2020. 'Cascade' is considered the cultivar most well adapted to the region and it has proven itself to be most tolerant to the environmental challenges identified. Other cultivars not included in the trial that have shown promise in Virginia and North Carolina include Saaz, Canadian Red Vine, and Kirin II.

Despite the difficulties encountered in the first 3 years, hops still retain great potential as a niche crop from which dedicated growers can realize income by working closely with local and regional craft breweries. On the research side, the prospects of the crop can be improved by further cultivar testing, prospecting for legacy hops that may be better adapted to local conditions, and harnessing the vast hop gene pool to develop new cultivars suited to the southeastern United States. Already, North Carolina State University has an active hop breeding program at the Mountain Horticultural Crops Research and Extension Center (Mills River, NC). Opportunities also exist for cross-disciplinary development of postharvest handling and processing tools and methods for small growers, and quality analysis and characterization for branding and marketing of local and regional hops.

\section{Literature cited}

American Society of Brewing Chemists. 2011. ASBC methods of analysis. 14th ed. Amer. Soc. Brewing Chemists, St. Paul, MN.

Brewers Association. 2019. National beer sales \& production data. 14 July 2020. <https://www.brewersassociation.org/ statistics/national-beer-sales-productiondata $/>$.

Brown, J.R. (ed.). 2011. Recommended chemical soil test procedures for the North Central region. North Central Reg. Res. Publ. Bull. No. 221. Missouri Agr. Expt. Sta. SB 1001. 12 Nov. 2020. $<$ https://extensiondata.missouri.edu/ pub/pdf/specialb/sbl001.pdf $>$.

Donner, P., J. Pokorný, J. Ježek, K. Krofta, J. Patzak, and J. Pulkrábek. 2020. Influence of weather conditions, irrigation and plant age on yield and alpha-acids content of Czech hop (Humulus lupulus L.) cultivars. Plant Soil Environ. 66:41-46, doi: https://doi. org/10.17221/627/2019-PSE.

Eriksen, R.L., L.K. Rutto, J.E. Dombrowski, and J.A. Henning. 2020. Photosynthetic activity of six hop (Humulus lupulus L.) cultivars under different temperature treatments. HortScience 55:403-409, doi: https://doi.org/10.21273/HORTSCI 14580-19.

Hop Growers of America. 2020. 2019 statistical report. 7 Jan. 2020. <https:// www.usahops.org/img/blog_pdf/273. pdf $>$.

Iskra, A.E., S.R. Lafontaine, K.M. Trippe, S.T. Massie, C.L. Phillips, M.C. Twomey,
T.H. Shellhammer, and D.H. Gent. 2019. Influence of nitrogen fertility practices on hop cone quality. J. Amer. Soc. Brew. Chem. 77:199-209, doi: https://doi. org/10.1080/03610470.2019.1616276.

Johnson, D.A., C.B. Skotland, and J.R. Alldredge. 1983. Weather factors affecting downy mildew epidemics of hops in the Yakima valley of Washington. Phytopathology 73:490-493.

Judd, B.D. 2018. Hops production in Virginia: Nutrition, fungal pathogens, and cultivar trials. Virginia Polytechnic Inst. State Univ., Blacksburg, MSc Diss. 30 Aug. 2020. <https://vtechworks.lib.vt. edu/handle/10919/86196 $>$.

Kuss, H.-M. 1992. Applications of microwave digestion technique for elemental analyses. Fresenius J. Anal. Chem. 343: 788-793.

Mahaffee, W.F., S.J. Pethybridge, and D.H. Gent. 2009. Compendium of hop diseases and pests. Amer. Phytopathol. Soc., St. Paul, MN.

Mehlich, A. 1984. Mehlich 3 soil test extractant: A modification of Mehlich 2 extractant. Commun. Soil Sci. Plant Anal. 15:1409-1416.

Méneret, G. and Svinareff. 1955. Les houblons de la recolte 1954. Brasserie 106:123-135.

Méneret, G. and Svinareff. 1956. Les houblons de la recolte 1955. Brasserie 119:205-216.

Neve, R.A. 1991. Hops. Chapman and Hall, London, UK.

Nita, M. 2020. Hops, p. 4(1)-4(10). In: C. Hong and E. Day (eds.). Field management guide for horticultural and forest crops. Virginia Coop. Ext. Publ. 456-017. 
9 Feb. 2021. <http://pubs.ext.vt.edu/ 456/456-017/456-017.html>.

O'Neal, S.D., D.B. Walsh, D.H. Gent, J.D. Barbour, R.A. Boydston, A.E. George, D.G. James, and J.D. Sirrine. 2015. Field guide for integrated pest management in hops. 3rd ed. 12 Oct. 2020. <https://www.usahops.org/cabinet/ data/Field-Guide.pdf $>$.

Potop, V. 2014. The impact of dry and wet events on the quality and yield of Saaz hops in the Czech hop growing regions. In: J. Rožnovský and T. Litschmann (eds.). Proc. Mendel a Bioklimatologie. 3-5 Sept. 2014. Brno, Czech Republic. 4 Aug. 2020. <http://cbks. cz/sbornikbrnol4/potop_1.pdf $>$.

Siegle, L. and H. Scoggins. 2017. 2016 Virginia hop grower survey: Results. Virginia Coop. Ext. ANR-292. 15 Nov. 2019. $<$ https://pubs.ext.vt.edu/content/dam/ pubs_ext_vt.../ANR-292.pdf $>$.

Siegle, L. and H. Scoggins. 2018. Virginia hop grower survey: Results. Virginia Coop. Ext. Publ. SPES-131. 15 Nov. 2019. <https://www.pubs.ext.vt.edu/content/ dam/pubs_ext_vt_edu/spes/spes-131/ SPES-131NP.pdf $>$.

Sirrine, R. 2016. The importance of testing hop fertility. 5 July 2016. <https://www. canr.msu.edu/news/the_importance_of_ testing_hop_fertility $>$.
Sirrine, J.R., N. Rothwell, E. Lizotte, R. Goldy, S. Marquie, and D.E. Brown-Rytlewski. 2010. Sustainable hop production in the Great Lakes region. Michigan State Univ. Coop. Ext. Bul. E-3083. 21 Dec. 2020. <https://www.uvm.edu/sites/default/ files/media/Sirrine-Sustainable-HopProduction-in-the-Great-Lakes-Region. pdf $>$.

Sirrine, R, E. Lizotte, D. Brown, T. O'Brien, and A. Leach. 2014. Estimated cost of producing hops in Michigan. Michigan State Univ. Ext. Publ. E-3236. 7 Dec. 2020. <https://www.canr.msu.edu/uploads / resources/pdfs/estimated_costs_of_ producing_hops_in_michigan_(e3236). pdf $>$.

Skotland, C.B. and D.A. Johnson. 1983. Control of downy mildew of hops. Plant Dis. 77:1183-1185.

Smith, L.P. 1970. The effect of temperature on the quality of hops. Rpt. Dept. Hop Res. Wye College for 1969. p. 45-60.

Srečec, S., I. Kvaternjak, D. Kaučić, A. Špoljar, and R. Erhatić. 2008. Influence of climatic conditions on accumulation of $\alpha$-acids in hop cones. ACS Agr. Conspec. Sci. 73:161-166.

Thomas, G.W. 1996. Soil $\mathrm{pH}$ and soil acidity, p. 475-490. In: D.L. Sparks (ed.). Methods of soil analysis: Part 3-
Chemical methods. Soil Sci. Soc. Amer., Madison, WI.

Thomas, G.G. 1980. Weather factors controlling the alpha-acid content of hops (Humulus lupulus L.). J. Hort. Sci. 55: 71-77.

Thomas, G.G. and P. Darby. 1984. Seasonal variation in alpha-acid content of hops in relation to environmental factors. Rpt. Dept. Hop Res. Wye College for 1983. p. $45-49$.

U.S. Environmental Protection Agency. 2014. Method 6010D (SW-846): Inductively coupled plasma-atomic emission spectrometry. Revision 4. 5 Sept. 2020. <https://www.epa.gov/esam/epamethod-6010d-sw-846-inductively-coupledplasma-atomicemission-spectrometry $>$.

Yakima Chief Hopunion. 2016. Hop variety handbook. 2016 ed. Yakima Chief Hopunion, Yakima, WA.

Zattler, F. 1960. Über die Beeinflussung des Bitterstoffgehaltes der Hopfendolden durch mikroklimatische Faktoren. Brauwelt 100:1402-1405.

Zattler, F. and J. Jehl. 1962. Über den Einfluß der Witterung auf Ertrag und Qualität des Hopfens in der Hallertau im Zeitabschnitt 1926-1961. Hopfen-Rundschau 13:61-64. 